\title{
Clinical Cytology and Thyroid Pathology
}

\author{
Shabalova IP* and Kasoyan KT \\ Russian Medical Academy of Continuous Professional Education, Russia
}

Submission: May 15, 2018; Published: August 10, 2018

*Corresponding author: Shabalova IP, Russian Medical Academy of Continuous Professional Education, Moscow,Russia, Email: irenshab@inbox.ru

\section{Mini Review}

This review is dedicated to the results of implementation of new methods in thyroid pathology in our country.Clinical Cytology(cytopathology) is a safe, painless and simple method of morphological diagnostics for detecting various pathological conditions. In Russiafine needle aspiration (FNA)was used during many years for many sites of a human body including thyroid[1-3]. Cytopathology is a widely known method, being close to histology to detect abnormal conditions and to choose the treatment by studying individual cells, structures and clusters of cells, their surroundings, transformation etc.The accuracy of cytological diagnosis by FNA in the most cases is identical to histological.In thyroid pathology it is highly important to access not only cytological picture, but hormonal and biochemical status [4]. Nowadays, that molecular and cytogenetic studies are gradually developing it's possible todetect and toidentify correctly various molecular targets especially in neoplastic lesions. The implementation of liquid based cytology of FNA showed that the gap between histology, cytology and molecular studies can be filledMorphological, molecular and genetic properties of cells are retained in preserve fluid. Combination of conventional smears (air-dried and MGG stained) and LBS (Papanicolaou stained) showed that both methods can and must be used together in clinical practice[5].In differential diagnostics of papillary carcinoma thyreoglobulin, TTF-1, HBME 1, galectin 3 are useful, in cases of benign lesions - CK19, p53, HBME[6]. Statistically significant difference between benign and molecular lesions has been obtained in the usage of Ki-67 ( $p<0,001)$ and $\beta$-katenin ( $p<$ 0,05 ) and the combination of them allowed to telldefinitely in doubtful cases about carcinoma in 45.5\%[7]. Scrapes from cytological slides, liquid-based cytology and cytoblocks (Cell blocks) can be used for molecular studies.Immunocytochemistry, flow cytometry, in situ hybridization on cytological slides (FISH. CISH, SISH), sequencing, PCR, RT-PCR (qRT-PCR), mRNA expression and other molecular studies are available nowadays[8-10]. Thus, multidisciplinary approach seems to be important, especially in difficult cases.In routine clinical practice the most often (up to $85 \%$ cases of FNA) thyroid pathology is non-toxical diffuse nodular goiter [11].FNA and intraoperative cytology can also be usefulautoimmune thyreoiditis, Graves disease and other non-neoplastic lesions[12-14].

\section{References}

1. Abramov MG (1948) Cytological diagnostics by puncture. Medicine, Moscow, Russia, p. 118.

2. Shiller-Volkova NN, Nikitina NI, Agamova KA, Brin ML (1964) Cytological diagnostics of malignant lesions.Medgiz, Atlas, Moscow, Russia, p. 263.

3. Shabalova IP, Sokolova VK (1996) Clinical Cytology in Russia: a brief review. Cytopathology 7(1): 54-55.

4. Dolgov VV, Shabalova IP, Kasoyan KT, Selivanova AV, Dzhangirova TV (2009) Thyroid. Hormonal and biochemical survey, cytological atlas, Tver, Russia, p. 132.

5. Brynova OV, Shabalova IP, Kasoyan KT (2015) Possibilities of liquidbased cytology in complex diagnostics of thyroid pathology. Laboratory, N2, p. 28.

6. Volchenko NN, Savostikova MV (2010) Atlas of cytological and immunocytochemical diagnostics of tumours, Moscow, Russia, p. 236.

7. Berjozkina IS, Saprina TV, Zima AP (2016) Possibilities of traditional and liquid-based cytology combined with immunocytochemical detection of some molecular markers in the preoperative diagnosis of well-differentiated thyroid cancer. Clinical and experimental thyreoidology 12(№1): 38-45.

8. Kasoyan KT, Shabalova IP, Zima AP (2016) Liquid-based cytology in thyroid pathology. Clinical Laboratory Diagnostics N4, Medicine, Moscow, Russia, pp. 225-228.

9. Volchenko NN, Slavnova EN, Tugulukova AA (2013) Liquid based cytology in oncology. Oncology N5: 26-31.

10. Tatiana Poloz (2018) Thyroid Tumors. In: Klijanienko J, Pohar Marinšek, Živa, Domanski, Henryk Adam, (Eds.), Small Volume Biopsy in Pediatric Tumors an Atlas for Diagnostic Pathology. Springer International Publishing AG pp. 289-304.

11. Vorobjev SL, Morphological diagnosis of Thyroid lesions (2014) SanktPeterburg, p. 104.

12. Volchenko NN (2004) Cytological diagnostics of tumous and tumourlike thyroid lesions. Russian Oncological Journal N6: 51-55.

13. Saprina TV, Prokhorenko TS, Rjazanceva NV (2015) Immunological and morphological predictors of clinical heterogeneity of patiens with Graves disease (resuls of intraoperative cytological diagnostics). The Bulletin of Siberian Medicine V 14: 81-91.

14. Saprina TV, Prokhorenko TS, Novitskij VV, Rjazanceva NV, Vorozcova IN (2017) Autoimmune thyroid diseases. Molecular approach in differential diagnostics p. 112. 

\begin{tabular}{l|l} 
(C) & $\begin{array}{l}\text { This work is licensed under Creative } \\
\text { Commons Attribution 4.0 Licens } \\
\text { DOI: 10.19080/JETR.2018.03.555624 }\end{array}$
\end{tabular}
Your next submission with Juniper Publishers will reach you the below assets

- Quality Editorial service

- Swift Peer Review

- Reprints availability

- E-prints Service

- Manuscript Podcast for convenient understanding

- Global attainment for your research

- Manuscript accessibility in different formats

( Pdf, E-pub, Full Text, Audio)

- Unceasing customer service

Track the below URL for one-step submission https://juniperpublishers.com/online-submission.php 